\title{
EFFECT OF SEED RATE AND WALKWAY ON YIELD OF FIELD PEA UNDER RELAY CROPPING WITH T. AMAN RICE
}

\author{
M. O. Ali ${ }^{1 *}$, A.H.M.M.R. Talukder ${ }^{2}$ and L. Nahar ${ }^{3}$ \\ ${ }^{1}$ Principal Scientific Officer, Pulses Research Sub-Station, BARI, Joydebpur, Gazipur-1701 \\ ${ }^{2}$ Scientific Officer, Plant Physiology Division, BARI, Joydebpur, Gazipur-1701 \\ ${ }^{3}$ Scientific Officer, Agronomy Division, BRRI, Joydebpur, Gazipur-1701 \\ ${ }^{*}$ Corresponding author, E-mail: omaraliprc@gmail.com
}

(Received: 30 December 2017, Accepted: 30 January 2018)

Keywords: seed rate, walking way, relay cropping and field pea

\begin{abstract}
The field experiment was conducted at Pulses Research Centre (PRC), Ishurdi, Pabna and Regional Agricultural Research Station (RARS), Jamalpur during rabi 2012-2013 to find out the effect of seed rate and walkway for green pea production as relay cropping with transplanted Aman rice. The experiment was based on six seed rates @ 50, 60, 70, 80, 90 and $100 \mathrm{~kg} \mathrm{ha}^{-1}$ and two walking ways viz. $15 \mathrm{~cm}$ wide walkway at 2 $\mathrm{m}$ interval over the plot and control with three replications. A local cultivar of pea, named Natore was used in this trial. Results revealed that the treatment with $100 \mathrm{~kg}$ seed ha $\mathrm{h}^{-1}$ gave the highest pod yield of $5.13 \mathrm{t} \mathrm{ha}^{-1}$ and $4.98 \mathrm{t} \mathrm{ha}^{-1}$ at Jamalpur and Ishurdi locations, respectively which was similar to $80\left(\mathrm{~S}_{4}\right)$ and $90\left(\mathrm{~S}_{5}\right) \mathrm{kg}$ seed ha ${ }^{-1}$. Walkway had no significant variation in yield and yield contributing characters but it produced the higher yield over the control. Using walkway, $100 \mathrm{~kg}$ seed ha- ${ }^{-1}\left(\mathrm{~S}_{6}\right)$ and $15 \mathrm{~cm}$ walkway at $2 \mathrm{~m}$ interval over the plot $\left(\mathrm{W}_{1}\right)$ produced the highest pod yield of $5.14 \mathrm{tha}^{-1}$ and $4.95 \mathrm{tha}^{-1}$ and fodder yield of $6.70 \mathrm{t} \mathrm{ha}^{-1}$ and $6.13 \mathrm{t} \mathrm{ha}^{-1}$ at Jamalpur and Ishurdi locations, respectively. Maximum gross margin of Tk. 1,06,040 ha- ${ }^{-1}$ and Tk. $1,02,401 \mathrm{ha}^{-1}$ was contributed by combinations of using $100 \mathrm{~kg}^{2}$ seed ha- $\mathrm{ha}^{-1} 15 \mathrm{~cm}$ walking way but maximum benefit cost ratio (BCR) of 3.40 and 3.43 were obtained from $\mathrm{S}_{5} \times \mathrm{W}_{1}$ combination at Jamalpur and Ishurdi locations, respectively. It is concluded that pea cultivar can be successfully cultivated for green pod production through the use of 90-100 $\mathrm{kg} \mathrm{ha}^{-1}$ seed with walkway of $15 \mathrm{~cm}$ wide in the plot after 2 m intervals.
\end{abstract}

\section{Introduction}

Pea (Pisum sativum), also known as the field or garden pea,is one of the most important and popular legume vegetable crops grown in many countries all over the world. According to FAO (2010), Pea is the fourth leading legume in terms of consumption in the world with a total production of 10.2 million tonnes. It is a good source of protein (21-25\%) (Bhat et al., 2013) and plays an important role in human nutrition since they are also rich in calories, vitamins and minerals. On the other hand, McKenzie and Sponer (1999) opined that Peas are widely grown for hay, pasturage or silage production either alone or mixed with cereals as relay and inter or mixed crop. Under this situation, relay and inter or mixed cropping would be an improved cropping technology to sow various pulses crops in the standing rice crop field, just before the harvest to ensure germination using the residual moisture and to avoid tillage operations. Earlier research conducted by Ali et al., (2018) revealed that local cultivar of pea named Natore would be extensively cultivated as relay crop with T. Aman rice under residual soil moisture.

Seed yield of pea obtained by local farmers in relay cropping or conventional system is quite low and variable. To meet up the future demand of nutrient for growing populations can be 
achieved by increasing area under field pea or maximizing yield unit $^{-1}$ area, by adopting appropriate production technology with use of optimum seed rate and proper management practices. Plant population is a yield limiting factor in field pea production that mainly influenced by seed rate. If more seed rate is used, plant population will be more and there will be competition among plants for water, nutrients and sunlight resulting in low quality and low yield. If less seed rate is used yield will be less due to lesser number of plants unit area ${ }^{1}$ (Attarde and Khuspe, 1989). An earlier study was conducted by Kibe and Kamithi (2007) and Dahmardeh et al. (2010) showed that seeding rate and cultivar are important factors affecting yield and quality of grain legumes. The competition ability of crops may be increased due to increasing seeding rate. As a result profitability of the crop may or may not increase owing to high seed cost in pulses. Rajput et al. (1989) concluded that maximum grain yield was obtained with the increase in seed rate, while minimum grain yield was produced by low seed rate. Consequently, as a relay cropping system field pea seed is broadcasted by the farmers into standing T. Aman rice at 10-15 days prior to harvest of rice. But the farmers' do not use optimum seed rate, sometimes use high or low which produced lower yield. Besides this, pea cultivar named Natore local is newly introduced in the research system which needs to find out the optimum seed rate for handsome yield as green pod and forage.

Conventionally, farmers do not keep any walkway in the plot to facilitate the pod picking. As a result during the harvesting of pod many immature or mature green pods may be destroyed by foot pressures that directly affect the final pod yield. Therefore, the experiment was conducted to find out the optimum seed rate and walkway for easily harvest of green pod for vegetable and forage without damaging of plants and immature pod under relay cropping with T. Aman rice to achieve higher yield.

\section{Materials and Methods}

The study was conducted at Pulses Research Centre (PRC), Ishurdi, Pabna, and Regional Agricultural Research Station (RARS), Jamalpur belongs to (AEZ-11) and (AEZ-9) respectively under Bangladesh Agricultural Research Institute (BARI), during rabi 2012-2013 to select suitable management practices viz. seed rate and walking way for the convenient of pod picking on yield of field pea var. Natore local as relay cropping with T. Aman rice which was found promising for green pod production through earlier screening program. The geographic coordinates of the research studied areas were located between $24.15^{\circ}$ north latitude and $89.0^{\circ}$

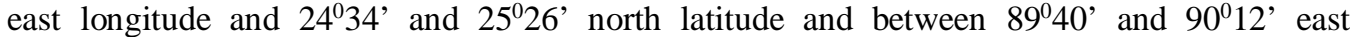
longitude respectively. The six seed rates $S_{1}=50, S_{2}=60, S_{3}=70, S_{4}=80, S_{5}=90, S_{6}=100 \mathrm{~kg} \mathrm{ha}^{-1}$ and two walking way viz. $\mathrm{W}_{1}=15 \mathrm{~cm}$ walking way was maintained after $2 \mathrm{~m}$ interval in the plot and $\mathrm{W}_{2}=$ control were used as a treatment. Considering the over location the unit plot size was maintained by $5 \mathrm{~m} \times \times 4 \mathrm{~m}$. The experiment was conducted under Randomized Complete Block design with three replications for both the locations. Seeds were soaked into water over a night to ensure the optimum germination prior to sowing. As per seed rate seeds were sown as relay cropping in the existing rice field before 15 days of rice harvest on 15 November, 2012 at Ishurdi and 29 October, 2012 at Jamalpur location. During seed sowing $15 \mathrm{~cm}$ walking way was maintained apart two meter in a plot. T. Aman was harvested leaving $30 \mathrm{~cm}$ straw height from ground level. No weeding was done during the whole crop growing period. Once a light irrigation $(1 \mathrm{~cm})$ was applied at 35 DAE for better crop establishment at Jamalpur location only. Pods were harvested at different dated on the basis of pod maturity as a green pod. Ten plants were selected randomly from each plot before harvest of crop to record data on yield attributes while pod yield was collected on the whole plot basis at different day's interval when bearing pod was matured as a green pod. Weight of fresh green pod obtained from the different harvests were recorded and summed up at the end of the crops life and converted into $\mathrm{t} \mathrm{ha}^{-1}$. Collected data were analyzed statistically following the ANOVA technique with the help of MSTAT-C 
software and mean separation was done as per LSD test according to Gomez and Gomez (1984). Variable cost of cultivation, gross margin and BCR were calculated considering the wages of local labour and input (seed) prices and selling prices of seed at the harvesting time. Economic analysis was done in terms of total cost of cultivation, net return and BCR. Benefit cost ratio was calculated by using following formula:

$$
\text { Benefit cost ratio }(\mathrm{BCR})=\frac{\text { Gross return }\left(\mathrm{Tk}_{\mathrm{ha}} \mathrm{-l}^{-1}\right)}{\text { Cost of Cultivation ( } \left.\mathrm{lk} \text { ha }{ }^{-1}\right)}
$$

\section{Results and Discussion}

\section{Weather information}

The mean maximum temperature $33.8^{\circ} \mathrm{C}$ and $31.1^{\circ} \mathrm{C}$ was attained during the period October'2012 at Jamalpur and Ishurdi locations respectively while mean minimum temperature $9.6^{\circ} \mathrm{C}$ and $12.7^{\circ} \mathrm{C}$ was attained during January' 2013 at Jamalpur and Ishurdi location respectively. $04 \mathrm{~mm}$ and $02 \mathrm{~mm}$ rainfall was prevailed at $1^{\text {st }}$ fortnight of October' 2012 and November'2012 respectively at Jamalpur location. But $05 \mathrm{~mm}$ rainfall was found at during $1^{\text {st }}$ fortnight of January'2013 at Ishwardi location.

Table 1 . Fortnightly maximum, minimum temperature $\left({ }^{\circ} \mathrm{C}\right)$ and total rainfall $(\mathrm{mm})$ at Jamlpur and Ishurdi location during rabi 2012-2013 during cropping season

\begin{tabular}{|c|c|c|c|c|c|c|c|c|}
\hline \multirow{3}{*}{ Month } & \multicolumn{3}{|c|}{ Jamalpur location } & \multirow[b]{3}{*}{$\begin{array}{c}\text { Rainfall } \\
(\mathrm{mm})\end{array}$} & \multicolumn{4}{|c|}{ Ishurdi location } \\
\hline & \multirow[t]{2}{*}{ Fortnight } & \multicolumn{2}{|c|}{$\begin{array}{c}\text { Temperature } \\
\left({ }^{\circ} \mathrm{C}\right)\end{array}$} & & \multirow[t]{2}{*}{ Fortnight } & \multicolumn{2}{|c|}{$\begin{array}{c}\text { Temperature } \\
\left({ }^{\circ} \mathrm{C}\right)\end{array}$} & \multirow{2}{*}{$\begin{array}{c}\begin{array}{c}\text { Rainfall } \\
(\mathrm{mm})\end{array} \\
\begin{array}{c}\text { Rainfall } \\
(\mathrm{mm})\end{array}\end{array}$} \\
\hline & & Max. & Min. & & & Max. & Min. & \\
\hline \multirow[t]{2}{*}{ Oct'12 } & $1^{\text {st }}$ fortnight & 33.8 & 23.8 & 04 & $1^{\text {st }}$ fortnight & 32.3 & 24.3 & 00 \\
\hline & $2^{\text {nd }}$ fortnight & 33.8 & 20.6 & 00 & $2^{\text {nd }}$ fortnight & 30.0 & 20.0 & 00 \\
\hline \multirow[t]{2}{*}{ Nov'12 } & $1^{\text {st }}$ fortnight & 29.5 & 18.6 & 02 & $1^{\text {st }}$ fortnight & 29.8 & 17.0 & 00 \\
\hline & $2^{\text {nd }}$ fortnight & 28.9 & 15.2 & 00 & $2^{\text {nd }}$ fortnight & 29.6 & 18.2 & 00 \\
\hline \multirow[t]{2}{*}{ Dec'12 } & $1^{\text {st }}$ fortnight & 25.6 & 13.9 & 00 & $1^{\text {st }}$ fortnight & 23.8 & 14.8 & 00 \\
\hline & $2^{\text {nd }}$ fortnight & 20.3 & 10.3 & 00 & $2^{\text {nd }}$ fortnight & 24.0 & 15.5 & 00 \\
\hline \multirow[t]{2}{*}{ Jan'13 } & $1^{\text {st }}$ fortnight & 19.9 & 9.3 & 00 & $1^{\text {st }}$ fortnight & 23.0 & 12.7 & 05 \\
\hline & $2^{\text {nd }}$ fortnight & 24.1 & 9.9 & 00 & $2^{\text {nd }}$ fortnight & 23.5 & 12.8 & 00 \\
\hline \multirow[t]{2}{*}{ Feb'13 } & $1^{\text {st }}$ fortnight & 26.8 & 13.8 & 00 & $1^{\text {st }}$ fortnight & 28.0 & 15.3 & 00 \\
\hline & $2^{\text {nd }}$ fortnight & 27.6 & 15.8 & 02 & $2^{\text {nd }}$ fortnight & 27.5 & 15.2 & 00 \\
\hline
\end{tabular}

\section{Effect of seed rate}

The results of seed rates are presented in Table 2. Days require attaining 50\% flowering of field pea variety of Natore local did not show significant variation among the different seed rates for both the locations. Considering the both locations it ranged from 45 to 47 days. Statistical analysis of the data revealed that seed rate had a significant $(\mathrm{P} \leq<0.01)$ effect on number of plant at per square meter at emergence. The number of plants $\mathrm{m}^{-2}$ was gradually increased with increasing seed rate and significantly maximum number (101 \& 98) of plants $\mathrm{m}^{-2}$ was obtained from the $100 \mathrm{~kg}$ seed $\mathrm{ha}^{-1}\left(\mathrm{~S}_{6}\right)$ at Jamalpur and Ishurdi locations, respectively. The minimum number $(50 \& 47)$ of plants at $\mathrm{m}^{-2}$ was found in $50 \mathrm{~kg}$ seed ha- ${ }^{-1}\left(\mathrm{~S}_{1}\right)$ treatment for both locations. Actually the number of plants $\mathrm{m}^{-2}$ was mainly influenced due to the variation of different seed rates. Similarly, Mujahid (1972), reported that plant density increases plants unit $\operatorname{area}^{-1}$ as the seed rate increases.

Shahzad et al., (2007) stated that height of the crop is mainly controlled by the genetic make up of a genotype and it can also be affected by the environmental factors. But plant height differed significantly among the different seed rate considering both the locations. Under this study plant 
height was increased linearly increasing plant population might be due to competition of plants in higher densities on light and space, resulting in taller plants. Considering the both locations the tallest plant $(116.0 \mathrm{~cm})$ and $(108 \mathrm{~cm})$ was noted in those plots where maximum seed rate $\left(100 \mathrm{~kg} \mathrm{ha}^{-1}\right)$ was sown that was statistically similar with seed rate of $90 \mathrm{~kg} \mathrm{ha}^{-1}$ while shortest plants $(101 \mathrm{~cm})$ and $(99.0 \mathrm{~cm})$ was recorded for those plots where lower seed rate $\left(50 \mathrm{~kg} \mathrm{ha}^{-1}\right)$ was sown for Jamalpur and Ishurdi locations respectively. Similarly, this finding was supported by Inanç and Yıldırım (2007), who indicated that denser plant population of pea increased plant height due to competition among plants.

Number of branches plant ${ }^{-1}$ differed significantly among the different seed rate in Ishurdi location while in Jamalpur location it showed non significant variation. Significantly maximum number of branches plant ${ }^{-1}$ was obtained from $50 \mathrm{~kg}$ seed $\mathrm{ha}^{-1}\left(\mathrm{~S}_{1}\right)$ at Ishurdi location other treatments gave the statistically similar and minimum number of branches plant ${ }^{-1}$ which might be due less population which got more light and space.

Pandey and Gritton (1975) stated that number of pods per plant is one of the most important components in determining the yield of several legume crops including pea. Meadley and Milbourn (1970) have well documented the response of pods per plant at differing densities of plant. Anderson and White (1974) reported that pod numbers per plant and peas per pod decreased with increasing density. Number of pod plant ${ }^{-1}$ differed significantly among different seed rate under the present studies and considering the both locations maximum number $(8.64 \&$ 8.06) of pods plant ${ }^{-1}$ was obtained from the $50 \mathrm{~kg}$ seed ha-1 $\left(\mathrm{S}_{1}\right)$ it might be due to the less intra plant competition that was statistically similar to the $60 \mathrm{~kg}$ and $70 \mathrm{~kg}$ seed ha-1 at Jamalpur and Ishurdi locations while the minimum number of pod plant ${ }^{-1}$ was obtained from the $100 \mathrm{~kg}$ seed ha $^{-1}$.

According to present research at two locations, increasing seeding rates decreased number of seeds per pod. Cousin (1997) stated that number of seeds per pod depends partially on the cultivar and on the environmental conditions but has also been documented to be affected by plant density. The highest number $(6.12 \& 5.84)$ of seeds /pod was obtained by $50 \mathrm{~kg} \mathrm{ha}^{-1}$ seed rate at Jamalpur and Ishurdi locations, respectively that was statistically similar with $60 \mathrm{~kg}$ and $70 \mathrm{~kg}$ seed ha ${ }^{-1}$ but the lowest number of seed / pod (5.04 and 4.68) was in $100 \mathrm{~kg} \mathrm{ha}^{-1}$ seed rate at Jamalpur and Ishurdi, respectively.

Significant variation was observed on pod and fodder yield $\left(\mathrm{t} \mathrm{ha}^{-1}\right)$ among the different seed rate for both the locations. The maximum pod yield $\left(5.13 \& 4.98 \mathrm{t} \mathrm{ha}^{-1}\right)$ was found from $100 \mathrm{~kg}$ seed $\mathrm{ha}^{-1}\left(\mathrm{~S}_{6}\right)$ seed rate which was statistically similar with $80 \mathrm{~kg}$ seed ha- $\mathrm{ha}^{-1}\left(\mathrm{~S}_{4}\right)$ and $90 \mathrm{~kg}$ seed ha$\left(\mathrm{S}_{5}\right)$ at Jamalpur location whereas at Ishurdi maximum pod yield $\left(4.98 \mathrm{tha}^{-1}\right)$ was found in 100 $\mathrm{kg}$ seed ha-1 which was statistically similar to $90 \mathrm{~kg}^{-1}$ seed ha- ${ }^{-1}$. It might be due optimum plant population with cumulative influence of yield contributing characters. Pod yield ( $\left.\mathrm{t} \mathrm{ha}^{-1}\right)$ was gradually increased with the increasing of seed rate. Similarly, Gan et al., (2003) reported that the seed yield of dry pea increased with increasing plant population densities from 30 to 80 plant $\mathrm{m}^{-2}$.

Fodder yields increased linearly with increasing seeding rates. Significantly, $100 \mathrm{~kg}$ seed ha-1 $\left(\mathrm{S}_{6}\right)$ produced maximum fodder yield $\left(6.68 \& 6.22 \mathrm{t} \mathrm{ha}^{-1}\right)$ at Jamalpur and Ishurdi location, respectively. It might be due to maximum plant stand which enhanced fodder production. Minimum fodder yield $\left(3.50 \mathrm{t} \mathrm{ha}^{-1}\right.$ and $2.47 \mathrm{t} \mathrm{ha}^{-1}$ was obtained from $50 \mathrm{~kg}$ seed ha ${ }^{-1}\left(\mathrm{~S}_{1}\right)$ at Jamalpur and Ishurdi locations, respectively.

Table 2. Effect of different seed rate on phenological, yield and yield attributes of pea as relay cropped with T.aman rice at Jamalpur and Ishurdi location during rabi 2012-2013

\begin{tabular}{lclll}
\hline $\begin{array}{l}\text { Seed rate } \\
\left(\mathrm{kg} \mathrm{ha}^{-1}\right)\end{array}$ & $\begin{array}{c}\text { Days to flowering } \\
\text { (Days) }\end{array}$ & $\begin{array}{l}\text { Number of plants } \\
\mathrm{m}^{-2} \text { at emergence }\end{array}$ & Plant height $(\mathrm{cm})$ & Branch plant $^{-1}$ (no.) \\
\hline
\end{tabular}




\begin{tabular}{lcccccccc}
\hline & Jamalpur & Ishurdi & Jamalpur & Ishurdi & Jamalpur & Ishurdi & Jamalpur & Ishurdi \\
\hline $\mathrm{S}_{1}$ & 46.0 & 46.0 & $50.0 \mathrm{e}$ & $47.0 \mathrm{f}$ & $101.0 \mathrm{~d}$ & $99.0 \mathrm{~b}$ & 1.11 & $1.34 \mathrm{a}$ \\
$\mathrm{S}_{2}$ & 46.0 & 46.0 & $61.0 \mathrm{~d}$ & $57.0 \mathrm{e}$ & $103.0 \mathrm{~cd}$ & $99.0 \mathrm{~b}$ & 1.18 & $1.17 \mathrm{~b}$ \\
$\mathrm{~S}_{3}$ & 47.0 & 47.0 & $71.0 \mathrm{c}$ & $68.0 \mathrm{~d}$ & $103.0 \mathrm{~cd}$ & $100.0 \mathrm{~b}$ & 1.16 & $1.16 \mathrm{~b}$ \\
$\mathrm{~S}_{4}$ & 45.0 & 45.0 & $81.0 \mathrm{bc}$ & $78.0 \mathrm{c}$ & $108.0 \mathrm{bc}$ & $100.0 \mathrm{~b}$ & 1.09 & $1.19 \mathrm{~b}$ \\
$\mathrm{~S}_{5}$ & 46.0 & 46.0 & $94.0 \mathrm{~b}$ & $88.0 \mathrm{~b}$ & $112.0 \mathrm{~b}$ & $105.0 \mathrm{ab}$ & 1.12 & $1.17 \mathrm{~b}$ \\
$\mathrm{~S}_{6}$ & 47.0 & 47.0 & $101.0 \mathrm{a}$ & $98.0 \mathrm{a}$ & $116.0 \mathrm{a}$ & $108.0 \mathrm{a}$ & 1.12 & $1.16 \mathrm{~b}$ \\
\hline $\mathrm{LSD}_{(0.05)}$ & NS & NS & 3.21 & 3.21 & 5.68 & 5.66 & NS & 0.07 \\
$\mathrm{CV}(\%)$ & 2.04 & 1.59 & 3.21 & 3.71 & 4.44 & 4.63 & 7.76 & 5.36 \\
\hline
\end{tabular}

Note: NS= non significance, ${ }^{*}=5 \%$ level of significance, $* *=1 \%$ level of significance; $\mathrm{S}_{1}=50 \mathrm{~kg}$ seed ha ${ }^{-1}$, $\mathrm{S}_{2}=60 \mathrm{~kg} \mathrm{seed} \mathrm{ha}^{-1}, \mathrm{~S}_{3}=70 \mathrm{~kg}$ seed ha $^{-1}, \mathrm{~S}_{4}=80 \mathrm{~kg} \mathrm{ha}^{-1}, \mathrm{~S}_{5}=90 \mathrm{~kg} \mathrm{ha}^{-1}, \mathrm{~S}_{6}=100 \mathrm{~kg} \mathrm{ha}^{-1}$

Table 2. (Contd.)

\begin{tabular}{lcccccccc}
\hline $\begin{array}{l}\text { Seed rate } \\
\left(\mathrm{kg} \mathrm{ha}^{-1}\right)\end{array}$ & \multicolumn{2}{c}{$\begin{array}{c}\text { Number of pod } \\
\text { plant }^{-1}\end{array}$} & \multicolumn{2}{c}{$\begin{array}{c}\text { Number of seed } \\
\text { pod }^{-1}\end{array}$} & \multicolumn{2}{c}{$\begin{array}{c}\text { Green pod yield } \\
\left(\mathrm{t} \mathrm{ha}^{-1}\right)\end{array}$} & \multicolumn{2}{c}{$\begin{array}{c}\text { Fodder yield } \\
\left(\mathrm{t} \mathrm{ha}^{-1}\right)\end{array}$} \\
\cline { 2 - 9 } & Jamalpur & Ishurdi & Jamalpur & Ishurdi & Jamalpur & Ishurdi & Jamalpur & Ishurdi \\
\hline $\mathrm{S}_{1}$ & $8.64 \mathrm{a}$ & $8.06 \mathrm{a}$ & $6.12 \mathrm{a}$ & $5.84 \mathrm{a}$ & $2.62 \mathrm{c}$ & $2.43 \mathrm{~d}$ & $3.50 \mathrm{e}$ & $2.47 \mathrm{e}$ \\
$\mathrm{S}_{2}$ & $8.58 \mathrm{a}$ & $7.70 \mathrm{a}$ & $5.61 \mathrm{ab}$ & $5.45 \mathrm{a}$ & $3.13 \mathrm{c}$ & $3.07 \mathrm{c}$ & $4.12 \mathrm{~d}$ & $3.84 \mathrm{~d}$ \\
$\mathrm{~S}_{3}$ & $8.20 \mathrm{a}$ & $7.54 \mathrm{ab}$ & $5.17 \mathrm{bc}$ & $5.30 \mathrm{ab}$ & $3.90 \mathrm{~b}$ & $3.26 \mathrm{c}$ & $4.78 \mathrm{c}$ & $4.67 \mathrm{c}$ \\
$\mathrm{S}_{4}$ & $7.05 \mathrm{~b}$ & $7.30 \mathrm{~b}$ & $5.50 \mathrm{bc}$ & $4.60 \mathrm{c}$ & $4.70 \mathrm{a}$ & $4.38 \mathrm{~b}$ & $5.35 \mathrm{~b}$ & $5.19 \mathrm{bc}$ \\
$\mathrm{S}_{5}$ & $6.50 \mathrm{~b}$ & $6.73 \mathrm{~b}$ & $5.06 \mathrm{c}$ & $4.83 \mathrm{bc}$ & $5.05 \mathrm{a}$ & $4.90 \mathrm{a}$ & $5.83 \mathrm{~b}$ & $5.49 \mathrm{~b}$ \\
$\mathrm{~S}_{6}$ & $6.42 \mathrm{~b}$ & $6.53 \mathrm{~b}$ & $5.04 \mathrm{c}$ & $4.68 \mathrm{c}$ & $5.13 \mathrm{a}$ & $4.98 \mathrm{a}$ & $6.68 \mathrm{a}$ & $6.22 \mathrm{a}$ \\
\hline $\mathrm{LSD}(0.05)$ & 0.78 & 0.78 & 0.54 & 0.569 & 0.58 & 0.39 & 0.57 & 0.57 \\
$\mathrm{CV}(\%)$ & 8.62 & 8.92 & 8.40 & 9.28 & 11.82 & 8.54 & 9.49 & 10.29 \\
\hline
\end{tabular}

Note: $\mathrm{S}_{1}=50 \mathrm{~kg}$ seed ha ${ }^{-1}, \mathrm{~S}_{2}=60 \mathrm{~kg}$ seed ha ${ }^{-1}, \mathrm{~S}_{3}=70 \mathrm{~kg} \mathrm{seed} \mathrm{ha}^{-1}, \mathrm{~S}_{4}=80 \mathrm{~kg} \mathrm{ha}^{-1}, \mathrm{~S}_{5}=90 \mathrm{~kg} \mathrm{ha}^{-1}, \mathrm{~S}_{6}=100$ $\mathrm{kg} \mathrm{ha}^{-1}$

According to result of two locations, an increase in seeding rate from 50 to $100 \mathrm{~kg}$ seeds ha-1 produced an approximately $91 \%$ and $152.0 \%$ increase in fodder yield. These results were consistent with the findings of Townley -Smith and Wright (1994).

\section{Effect of walkway way on yield and yield contributing characters}

The results presented in the Table 3 revealed that none of the variables showed significant variation between the walking ways for both the locations. But numerically, the higher pod and fodder yield of $4.16 \mathrm{t} \mathrm{ha}^{-1} \& 5.05 \mathrm{t} \mathrm{ha}^{-1}$ for Jamalpur, and $3.88 \mathrm{t} \mathrm{ha}^{-1} \& 4.65 \mathrm{t} \mathrm{ha}^{-1}$ for Ishurdi locations were obtained from the walking way, $15 \mathrm{~cm}$ after $2 \mathrm{~m}$ interval in the plot and the lower pod and fodder yield was in control. It might be due to the less affect on plant by foot pressure during pod harvesting.

Table 3. Effect of walkway facilities on phenological, yield and yield attributes pea with T.aman rice at Jamalpur and Ishurdi location during rabi 2012-2013

\begin{tabular}{lcccccccc}
\hline \multirow{2}{*}{$\begin{array}{l}\text { Path } \\
\text { facilities }\end{array}$} & \multicolumn{2}{c}{$\begin{array}{c}\text { Days to flowering } \\
\text { (Days) }\end{array}$} & \multicolumn{2}{c}{$\begin{array}{c}\text { Number of plants } \mathrm{m}^{-2} \\
\text { at emergence }\end{array}$} & Plant height (cm) & \multicolumn{2}{c}{ Branch plant ${ }^{-1}$ (no.) } \\
\cline { 2 - 9 } & Jamalpur & Ishurdi & Jamalpur & Ishurdi & Jamalpur & Ishurdi & Jamalpur & Ishurdi \\
\hline $\mathrm{W}_{1}$ & 46.0 & 46.0 & 76.0 & 71.5 & 106.0 & 102.3 & 1.16 & 1.204 \\
$\mathrm{~W}_{2}$ & 46.0 & 46.0 & 76.0 & 73.2 & 108.0 & 101.6 & 1.11 & 1.191 \\
\hline $\mathrm{LSD}_{0.05}$ & $\mathrm{NS}$ & $\mathrm{NS}$ & $\mathrm{NS}$ & $\mathrm{NS}$ & $\mathrm{NS}$ & $\mathrm{NS}$ & $\mathrm{NS}$ & $\mathrm{NS}$ \\
$\mathrm{CV}(\%)$ & 2.04 & 1.59 & 3.52 & 3.71 & 4.44 & 4.63 & 7.76 & 5.36 \\
\hline
\end{tabular}


$\mathrm{NS}=$ non significance, $\mathrm{W}_{1}=15 \mathrm{~cm}$ wide walkway way at $2 \mathrm{~m}$ interval over the plot and $\mathrm{W}_{2}=$ Control

Table 3 Contd.

\begin{tabular}{lcccccccc}
\hline $\begin{array}{l}\text { Path } \\
\text { facilities }\end{array}$ & \multicolumn{2}{c}{$\begin{array}{c}\text { Number of pods } \\
\text { plant }\end{array}$} & \multicolumn{2}{c}{$\begin{array}{c}\text { Number of seeds } \\
\text { pod }^{-1}\end{array}$} & \multicolumn{2}{c}{$\begin{array}{c}\text { Pod yield } \\
\left(\mathrm{t} \mathrm{ha}^{-1}\right)\end{array}$} & \multicolumn{2}{c}{$\begin{array}{c}\text { Fodder yield } \\
\left(\mathrm{t} \mathrm{ha}^{-1}\right)\end{array}$} \\
\cline { 2 - 9 } & Jamalpur & Ishurdi & Jamalpur & Ishurdi & Jamalpur & Ishurdi & Jamalpur & Ishurdi \\
\hline $\mathrm{W}_{1}$ & 7.55 & 7.15 & 5.32 & 5.13 & 4.16 & 3.88 & 5.05 & 4.65 \\
$\mathrm{~W}_{2}$ & 7.56 & 7.48 & 5.51 & 5.10 & 4.01 & 3.79 & 5.01 & 4.64 \\
\hline $\mathrm{LSD}_{0.05}$ & $\mathrm{NS}$ & $\mathrm{NS}$ & $\mathrm{NS}$ & $\mathrm{NS}$ & $\mathrm{NS}$ & $\mathrm{NS}$ & $\mathrm{NS}$ & $\mathrm{NS}$ \\
$\mathrm{CV}(\%)$ & 8.62 & 8.92 & 8.40 & 9.28 & 11.82 & 8.54 & 9.49 & 10.29 \\
\hline
\end{tabular}

$\mathrm{NS}=$ non significance, $\mathrm{W}_{1}=15 \mathrm{~cm}$ walking way at $2 \mathrm{~m}$ interval over the plot and, $\mathrm{W}_{2}=$ Control

\section{Interaction effect of seed rate and walkway}

The results showed that none of variables did not differ significantly due to the interaction effect of seed rate and walking way for both the locations. Anyway, numerically the highest pod yield of 5.14 and $4.95 \mathrm{t} \mathrm{ha}^{-1}$ was produced by $\mathrm{S}_{6} \times \mathrm{W}_{1}$ combination at Jamalpur and Ishurdi, respectively. Similar treatment also produced the highest fodder yield 6.70 and $6.13 \mathrm{tha}^{-1}$ at Jamalpur and Ishurdi, respectively.

\section{Economic performance}

Considering th locations, maximum cost of cultivation was Tk. 45,000 ha-1 and Tk. 43,500 ha-1 for $\mathrm{S}_{6} \times \mathrm{W}_{1}$ combination and the combination of $\mathrm{S}_{1} \times \mathrm{W}_{2}$ needed minimum cost of cultivation was Tk. 40,000 ha- and Tk. 38,000 ha- at Jamalpur and Ishurdi location, respectively (Table 4). Cost of cultivation was mainly varied among the combinations which might be due to the variation of seed rate. The maximum gross return Tk. 1, 51,040 was found from $\mathrm{S}_{6} \times \mathrm{W}_{1}$ combination at Jamalpur while at Ishurdi Tk.1, 45,910 ha- was found from same combination. Maximum gross margin of TK. 1, 06,040 ha ${ }^{-1}$ and Tk. 1,02,550 ha ${ }^{-1}$ were obtained from the treatment combination of $\mathrm{S}_{6} \times \mathrm{W}_{1}$ at Jamalpur, and Ishurdi locations, respectively. At Jamalpur and Ishurdi location maximum benefit cost ratio (BCR) 3.40 and 3.43 was obtained from $\mathrm{S}_{5} \times \mathrm{W}_{1}$ combination which was very similar to $\mathrm{S}_{5} \times \mathrm{W}_{2}, \mathrm{~S}_{6} \times \mathrm{W}_{1}$ and $\mathrm{S}_{6} \times \mathrm{W}_{2}$ combinations (Table 4 contd.).

Table 4. Economic performances of seed rate and walkway way on yield of peas as relay cropped with T. aman rice at Jamalpur and Ishurdi location during rabi 2012-2013

\begin{tabular}{lcccccc}
\hline Varieties & \multicolumn{2}{c}{$\begin{array}{c}\text { Pod yield } \\
\left(\mathrm{t} \mathrm{ha} \mathrm{h}^{-1}\right)\end{array}$} & \multicolumn{2}{c}{$\begin{array}{c}\text { Fodder yield } \\
\left(\mathrm{t} \mathrm{ha}^{-1}\right)\end{array}$} & \multicolumn{2}{c}{$\begin{array}{c}\text { Cost of cultivation } \\
(\text { Tk. ha }\end{array}$} \\
\cline { 2 - 7 } & Jamalpur & Ishurdi & Jamalpur & Ishurdi & Jamalpur & Ishurdi \\
\hline $\mathrm{S}_{1} \times \mathrm{W}_{1}$ & 2.90 & 2.65 & 3.50 & 2.50 & 40,000 & 38500 \\
$\mathrm{~S}_{1} \times \mathrm{W}_{2}$ & 2.34 & 2.20 & 3.43 & 2.43 & 40,000 & 38000 \\
$\mathrm{~S}_{2} \times \mathrm{W}_{1}$ & 3.11 & 3.04 & 4.13 & 3.77 & 41,200 & 39400 \\
$\mathrm{~S}_{2} \times \mathrm{W}_{2}$ & 3.15 & 3.09 & 4.12 & 3.91 & 41,200 & 39000 \\
$\mathrm{~S}_{3} \times \mathrm{W}_{1}$ & 3.95 & 3.32 & 4.90 & 4.73 & 42,000 & 40500 \\
$\mathrm{~S}_{3} \times \mathrm{W}_{2}$ & 3.85 & 3.20 & 4.65 & 4.60 & 42,000 & 40100 \\
$\mathrm{~S}_{4} \times \mathrm{W}_{1}$ & 4.65 & 4.42 & 5.30 & 5.18 & 43,000 & 41,300 \\
$\mathrm{~S}_{4} \times \mathrm{W}_{2}$ & 4.75 & 4.35 & 5.40 & 5.20 & 43,000 & 40,900 \\
$\mathrm{~S}_{5} \times \mathrm{W}_{1}$ & 5.10 & 4.92 & 5.80 & 5.59 & 43,800 & 42,000 \\
$\mathrm{~S}_{5} \times \mathrm{W}_{2}$ & 4.99 & 4.89 & 5.85 & 5.40 & 43,800 & 41,700 \\
$\mathrm{~S}_{6} \times \mathrm{W}_{1}$ & 5.14 & 4.95 & 6.70 & 6.13 & 45,000 & 43,500 \\
$\mathrm{~S}_{6} \times \mathrm{W}_{2}$ & 5.11 & 4.91 & 6.65 & 5.95 & 45,000 & 43,000 \\
\hline
\end{tabular}

Table 4 (contd) 


\begin{tabular}{lcccccc}
\hline Varieties & \multicolumn{2}{c}{$\begin{array}{c}\text { Gross return } \\
(\text { Pod }+ \text { fodder })\end{array}$} & \multicolumn{2}{c}{$\begin{array}{c}\text { Gross margin } \\
(\text { Tk. ha }\end{array}$} \\
& \multicolumn{2}{c}{$($ Tk. ha $)$} & & & BCR \\
& & & & & \\
& Jamalpur & Ishurdi & Jamalpur & Ishurdi & Jamalpur & Ishurdi \\
\hline $\mathrm{S}_{1} \times \mathrm{W}_{1}$ & 83,300 & 76,550 & 43,300 & 38,050 & 2.08 & 1.99 \\
$\mathrm{~S}_{1} \times \mathrm{W}_{2}$ & 68,040 & 64,260 & 28,040 & 26,260 & 1.70 & 1.69 \\
$\mathrm{~S}_{2} \times \mathrm{W}_{1}$ & 91,510 & 89,620 & 50,310 & 50,220 & 2.22 & 2.27 \\
$\mathrm{~S}_{2} \times \mathrm{W}_{2}$ & 92,870 & 91,250 & 51,670 & 52,250 & 2.25 & 2.34 \\
$\mathrm{~S}_{3} \times \mathrm{W}_{1}$ & $1,16,110$ & 99,100 & 74,110 & 58,600 & 2.76 & 2.45 \\
$\mathrm{~S}_{3} \times \mathrm{W}_{2}$ & $1,13,150$ & 95,600 & 71,150 & 55,500 & 2.69 & 2.38 \\
$\mathrm{~S}_{4} \times \mathrm{W}_{1}$ & $1,35,910$ & $1,29,700$ & 92,910 & 88,400 & 3.16 & 3.14 \\
$\mathrm{~S}_{4} \times \mathrm{W}_{2}$ & $1,38,650$ & $1,27,850$ & 95,650 & 86,950 & 3.22 & 3.13 \\
$\mathrm{~S}_{5} \times \mathrm{W}_{1}$ & $1,48,880$ & $, 144,020$ & $1,05,080$ & $1,02,020$ & 3.40 & 3.43 \\
$\mathrm{~S}_{5} \times \mathrm{W}_{2}$ & $1,45,530$ & $1,42,830$ & $1,01,730$ & $1,01,130$ & 3.32 & 3.43 \\
$\mathrm{~S}_{6} \times \mathrm{W}_{1}$ & $1,51,040$ & $1,45,910$ & $1,06,040$ & $1,02,410$ & 3.36 & 3.35 \\
$\mathrm{~S}_{6} \times \mathrm{W}_{2}$ & $1,49,870$ & $1,44,470$ & $1,04,870$ & $1,01,470$ & 3.33 & 3.36 \\
\hline
\end{tabular}

\section{Price}

Motorshuti pod :Tk. $27 \mathrm{~kg}^{-1}$ (mean values of two locations); fodder - Tk. $2 \mathrm{~kg}^{-1}$, (mean values of two locations), Pod harvesting @ Tk. $8 \mathrm{~kg}^{-1}$ (mean value of two locations)

\section{Conclusion}

The aforesaid results of two locations indicated that seed rate had significant effect on yield in field pea. The highest pod yield of $5.13 \mathrm{t} \mathrm{ha}^{-1}$ and $4.98 \mathrm{t} \mathrm{ha}^{-1}$ was obtained from using $100 \mathrm{~kg}$ seed $\mathrm{ha}^{-1}$ at Jamalpur and Ishurdi, respectively which showed statistically similar results obtained from using 80 and $90 \mathrm{~kg}$ seed ha-1 at Jamalpur $90 \mathrm{~kg} \mathrm{ha}^{-1}$ at Ishurdi. In conclusion, 90$100 \mathrm{~kg}$ seed ha ${ }^{-1}$ can be recommended for extensive cultivation of field pea as a relay crop with T. Aman rice. Though walkway facilities did not show any significant variation in pod yield but walk way it can be recommended for easy and smart-picking of green pod without damaging the crop.

\section{References}

Ali, M.O., A. Sarker, A. H. M. M. R.Talukder, M. S.Alam,M. A. Islam and J. Hossain. 2018. Adaptation of pea (Pisum sativum L) as relay crop with monsoon rice is a resource conservation technology in medium high to medium low lands of Bangladesh. Global Adv. Res. J. Agric. Sci. 7(1):011-019.

Anderson, J. A. D. and J. G. H. White. 1974. Yield of green peas. II. Effects of water and plant density. New Zealand J. Exp. Agric. 2: 165-171.

Attarde, D. R. and V. S. Khuspe. 1989. Response of wheat varieties to different levels of seed rate and nitrogen. J. Maharashtra Agric. Univ. 4: 309-310.

Bhat, T.A. M.,M. Gupta, M. A. Ganai, R. A. Ahanger and H. A. Bhat. 2013. Yield, soil health and nutrient utilization of field pea (Pisum sativum L.) as affected by phosphorus and Biofertilizers under subtropical conditions of Jammu. Int. J. Modern Plant Animal Sci. 1(1):1-8.

Cousin, R. 1997. Peas (Pisum sativum L.). Field Crops Res. 53: 111-130.

Dahmardeh, M., M. Ramroodi and J. Valizadeh. 2010. Effect of Plant Density and Cultivars on Growth, Yield and Yield Components of Faba Bean (Vicia faba L.). Afr J. of Biot. 9(50): 8643-8647. 
FAO (Food and Agricultural Organization of the United Nations) 2010. http://faostat.fao.org/site/339/default.aspx

Gan, Y. T., P. R. Miller, B. G. McConkey, R. P. Zentner, P. H. Liu and C. L. McDonald. 2003. Optimum Plant Population Density for Chickpea and Dry pea in a Semiarid Environment. Can. J. Plant Sci. 83: 1-9.

Gomez, A. A. and A. A Gomez. 1984. Statistical procedures of Agricultural Research. John Wiley and Sons, New York, 20-21.

Inanç, S and B. Yıldırım. 2007. The Effect of Different Row Space Applications on the Yield and Yield Components in Pea (Pisum sativum L.). Turkish VII. Field Crops Cong. 25-27 July, Erzurum.

Kibe, A. M. and D. K. Kamithi. 2007. Production Potential of Desi Chickpea Grown under Various Nitrogen and Planting Densities at Naivasha. Agril. J. 2(4): 520-525.

McKenzie, D. B. and D. Sponer. 1999. White lupin: an alternative to pea in oat-legume forage mixtures grown in New Found land. Can. J. Plant Sci. 79: 43-47.

Meadley, J. T. and G. M. Milbourn. 1970. The growth of vining peas. II. The effect of density of planting. Journal of Agril. Sci. Cambridge. 74: 273-278.

Mujahid, Z. H. 1972. Effect of row spacing and seed rate on the growth and yield of wheat variety chenab-70. M.Sc. Thesis, University of Agriculture, Faisalabad, Pakistan.

Pandley, S. and E. T. Gritton. 1975. Genotypic and Phenotypic Variances and Correlations in Peas. Can. J. Plant Sci. 3: 353-356.

Rajput, F. K., M. M. J. Rajput, S. M. Aslam and A. W. Baloch. 1989. The growth and yield of wheat as affected by different seed rates and raw spacing. Sarhad J. Agric. 5: 479-482.

Shahzad, M. A., W. U. Din, S. T. Sahi, M. M. Khan, Ehsanullah and M. Ahmad. 2007. Effect of sowing dates and seed treatment on grain yield and quality of wheat. Pakistan J. Agri. Sci. 44 (4): 581-583.

Townley-Smith, L. and A. T. Wright. 1994. Field pea cultivar and weed response to crop seed rate in western Canada. Can. J. Plant Sci. 74: 387-393. 